\begin{tabular}{|l|l|l|}
\hline \multicolumn{2}{|c|}{ PublisherInfo } \\
\hline \hline PublisherName & $:$ & BioMed Central \\
\hline \hline PublisherLocation & $:$ & London \\
\hline \hline PublisherImprintName & $:$ & BioMed Central \\
\hline \hline
\end{tabular}

\title{
BMP-2 induces osteoblast apoptosis mediated by PKC
}

\begin{tabular}{||l|l|l||}
\hline \multicolumn{2}{|c|}{ ArticleInfo } \\
\hline \hline ArticleID & $:$ & 289 \\
\hline \hline ArticleDOI & $:$ & $10.1186 /$ ar-2002-74601 \\
\hline \hline ArticleCitationID & $:$ & 74601 \\
\hline \hline ArticleSequenceNumber & $:$ & 42 \\
\hline \hline ArticleCategory & $:$ & Paper Report \\
\hline \hline ArticleFirstPage & $:$ & 1 \\
\hline \hline ArticleLastPage & $:$ & 3 \\
\hline \hline & & RegistrationDate : 2002-1-16 \\
& $:$ & Received \\
ArticleHistory & & Accepted $2002-1-16$ \\
& $: 2002-1-25$ \\
\hline \hline ArticleCopyright & $:$ & Biomed Central Ltd2002 \\
\hline \hline ArticleGrants & $:$ & \\
\hline \hline
\end{tabular}




\begin{tabular}{|l|l|l|}
\hline ArticleContext & $:$ & 130754411 \\
\hline
\end{tabular}

Tsutomu Takeuchi, ${ }^{\text {Aff1 }}$

Affl Dept. of Internal Medicine, Saitama Medical Center, Saitama Medical

School, Saitama, Japan

\section{Keywords}

apoptosis, BMP-2, osteoblasts, PKC, TGF-?

\section{Context}

Apoptosis of osteoblasts is a key to controlling osteoblast life span and bone formation, in addition to differentiation of progenitor cells. There are two types of regulators of osteoblast apoptosis: osteotropic hormones and local regulatory cytokines, such as tumor necrosis factor-a, interleukin- 1 and -6 , insulinlike growth factor-1, and fibroblast growth factor. Although it is well known that bone morphogenic proteins (BMPs) play a pivotal role in the commitment and differentiation of osteoblastic lineage, their role in apoptosis induction remains unknown.

\section{Significant findings}

BMP-2 promotes apoptosis in primary human calvariae and immortalized neonatal osteoblasts, while TGF-? inhibits apoptosis. BMP-2 increases the release of mitochondrial cytochrome $\mathrm{c}$ to the cytosol, the Bax/Bcl-2 ratio, and caspase- $9,-3,-6$, and -7 activity. When mutant Smad-1 is transfected in a dominant-negative fashion BMP-2-induced expression of osteoblast transcription factor Runx2 is downregulated, whereas the caspase activation and apoptosis is not affected. BMP-2 upregulates PKC activity and its inhibitor blocks osteoblasts-apoptosis induced by BMP-2, indicating that the proapoptotic effect of BMP-2 is PKC-dependent.

\section{Comments}


A novel role for BMP-2 in the induction of apoptosis in human osteoblasts has been demonstrated, although the ability to induce apoptosis by BMP-2 was not compared with other pro-inflammatory cytokines. The signaling pathway leading to apoptosis induction is not dependent on Smad, which is necessary for BMP-2-induced osteoblast differentiation, but on PKC. Given that the regulation of apoptosis in osteoblasts is pivotal to the control of bone formation, the results introduce a possibility that one can selectively modulate the BMP-2/apoptosis pathway without affecting osteoblast differentiation. It would be of interest to know whether apoptosis induced by proinflammatory cytokines other than BMP-2 can be inhibited by a selective PKC inhibitor.

\section{Methods}

TUNEL-staining, in vitro enzyme activity measurements, western blot, in vitro transfection

\section{Additional information}

\section{References}

1. Hay E, Lemonnier J, Fromigue O, Marie PJ: Bone morphogenetic protein-2 promotes osteoblast apoptosis through a Smad-independent, protein kinase C-dependent signaling pathway. J Biol Chem. 2001, 276: 29028-29036.

This PDF file was created after publication. 